\section{REPORT OF MEETINGS, ACRL ART SUBSECTION}

Atlantic City, New Jersey

June 23-June 27, 1969

Chairman, Herbert Scherer, Art Library, University of Minnesota, Minneapolis, Minnesota; Vice-Chairman and Chairman-Elect, Wolfgang Freitag, Fine Arts Library, Fogg Art Museum, Harvard University, Cambridge, Massachusetts; Secretary, Nancy Johanson, Art Department, Minneapolis Public Library, Minneapolis, Minnesota.

Monday, June 23: Trip to Princeton University arranged by Judith Hoffberg, Program Chairman, University of Pennsylvania Art Library. The group visited the handsome new Art Library in McCormack Hall. Miss Frederica Oldach, the Librarian, explained the rationale and the procedure for the Reference Library. She pointed out the special accommodations for faculty and graduate students and equipment for oversize books. Dr. Rosalie Green, Director of the Index of Christian Iconography, graciously spoke about the function and history of that special project. Dr. David Coffin, Chairman of the Department of Art History, spoke of the advantages of having the Department of Art History, the University Art Museum, and the Art Library under one roof. $\mathrm{He}$ and Miss Oldach and Dr. Green acted as hosts at a reception sponsored by the Department of Art History in the new gallery.

Business meetings were held from June 24 through June 26. The following summarizes the various committee reports, new committees formed, and discussion.

\section{RePRint COMMitTEe Report}

William Dane, Newark Public Library,

Newark, N.J.

Further disposition of the out-of-print want list compiled by the Reprint Committee and published in College \& Research Libraries News (April 1969) was discussed. The list was sent to twelve reprint or microfilm publishers. To date there have been responses from six firms expressing appreciation for the list and a general interest in its content. Of the fifty-one book titles suggested, one has

ACRI. Membership

January 31, 1970

14,131

January 31, 1969

January 31, 1968

13,020

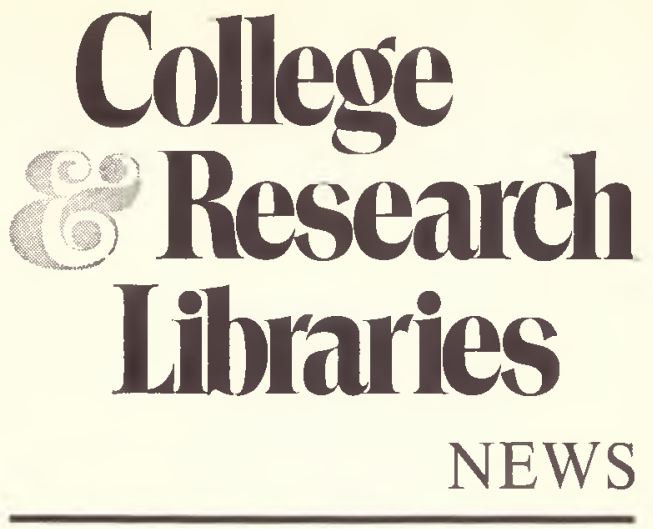

News Editor, Michael Herbison, Casper College, Casper, Wyoming 82601.

Editor, Richard M. Dougherty, University of Colorado Libraries, Boulder, Colorado 80302.

Editorial Board: Richard DeGennaro, Harvard University; David HERON, University of Kansas; Ellsworth Mason, Hofstra University; Fred Heinatiz, Southern Connecticut State College; WiLliam AxForD, Florida Atlantic University; Peter Hiat, Indiana University.

ACRL Officers, 1969/70: President, Philip J. McNiff; Chairman, College Libraries Section, John E. Scott, Junior College Libraries Section, Ruthe Erickson; Rare Books Section, Robert J. Adelsperger; Subject Specialists Section, Marcia Y. Miller; Agriculture and Biological Sciences Subsection, Howard Rovelstad; Art Subsection, Wolfgang M. Freitag; Educational and Behavioral Science Subsection, Donald Leatherman; Law and Political Science Subsection, Roy M. Mersky; Slavic and East European Subsection, Joseph Placek; University Libraries Section, Roscoe Rouse.

News from the Field, Personnel profiles and notes, classified advertising, official matter of ACRL, and other material of a timely nature is published in the News issues of College \& Research Libraries.

Inclusion of an article or advertisement in CRL does not constitute official endorsement by ACRL or ALA.

Production and Advertising and Circulation office: 50 E. Huron St., Chicago, Ill. 60611. Change of address and orders for subscriptions should be addressed to College if Research Libraries, for receipt at the above address, at least two months before the publication date of the effective issue.

Subscription to $C R L$ is included in membership dues to $A C R L$ of $\$ 6$ or more; other subscriptions to $C R L$ are $\$ 10$ per year. Neither subscriptions nor memberships include miscellaneous unscheduled supplements, which are available by purchase only. Retroactive subscriptions are not accepted. Single journal copies are available at $\$ 1.50$ each and News issues at $\$ 1.00$ each from ALA Publishing Department.

Indexed in Current Contents, Library Literature, and Science Citation Index. Abstracted in Library Science Abstracts. Book reviews indexed in Book Review Index.

College \& Research Libraries is the official journal of the Association of College and Research Libraries, a division of the American Library Association; and is published seventeen times per year-bi-monthly as a technical journal with 11 monthly News issues, combining July-August-at 1201-05 Bluff St., Fulton, Mo. 65251.

Second-class postage paid at Fulton, Mo. 


\section{BRAND NEW}

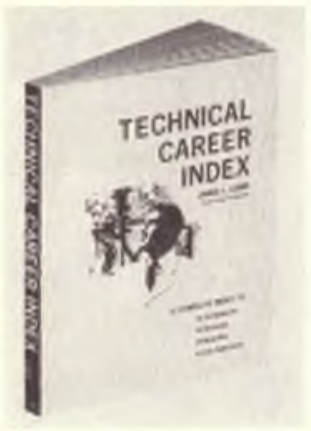

\section{TECHNICAL CAREER INDEX}

by James L. Lubin

A detailed index to the salaries and benefits schedules of 500 major American corporations. A roster of job opportunities and a description of the types of engineers and scientists sought by the nation's technical employers. Separate sections on technical manpower recruiting, choosing a company, and negotiating salaries. 265 pp $\$ 4.95$

\section{THE LUBIN REPORT}

A comparative guide to corporate salary and benefit programs. Over fifty graphs and tables describe corporate practice in vacation plans, educational assistance, military deferments, pensions, profit sharing, and dozens of other benefit policy areas. Also contains commentary and analysis of current business practice in salary and benefit programs. Based on a survey of 1600 major American companies. $70 \mathrm{pp} \$ 12.50$

For a complete catalog of other technical books write:

\section{PADRIC PUBLISHING COMPANY}

Box 393-Bernardsville, N.J. 07924 been reprinted, three are in production, and there was a definite interest in eight others. Open discussion followed on further action to be taken on reprinting the list. Cost, standards, a subscription plan, and the responsibilities of libraries in making materials available to publishers were considered. Motion was made and carried that the Reprint Committee should be maintained for continued action. William Dane, Newark Public Library, will continue to receive suggestions for out-of-print titles which will again be compiled and listed in CRL News.

Newsletter and Buffalo Art Librarians" Confference Report

Mrs. Florence DaLuiso, State University of New York at Buffalo.

Mrs. DaLuiso outlined the steps taken in organizing the conference in Buffalo between June 16 and June 20 titled "Art Libraries: Their Comprehensive Role in Preserving Visual Resources." Comment was made that many libraries were unaware of the conference and that no good up-to-date mailing list of art libraries was available. The list was assembled from the American Art Directory, the International Directory of Arts, and the available list of ALA members. Brochures were mailed to academic institutions and museum libraries. Dr. Freitag mentioned that there are 1,062 members of the Art Subsection. The following day at the Divisional meeting the chairman requested that a printout of the subsection membership be made available to members.

\section{Committee on Professional Status}

It was moved that a committee be formed to make an attempt to influence institutions to provide funds for librarians to attend ALA conferences. Motion was carried and a committee was formed with Hazel Guston, Philadelphia College of Art, Philadelphia, Pennsylvania, as chairman.

\section{Indexing Committee Report}

Herbert Scherer, Art Library, University of Minnesota, Minneapolis.

Indexing Committee for a retrospective indexing of Art International met Wednesday, June 25, at the Traymore Hotel. Eight members were present and agreed to proceed with indexing specific years of this periodical. Previously formulated rules and procedures were reviewed and revised. Contact was made following the convention with the editor of Art International who agreed to publish the index prepared by the committee.

\section{Open Forum \\ Wolfgang Freitag, Fine Arts Library, Fogg}


Art Museum, Harvard University, Cambridge, Massachusetts.

The failure of the Library of Congress to catalog art exhibition catalogs was brought to the attention of the members. It was generally felt that LC is not fulfilling its mandate to do so and Dr. Freitag formulated a letter urging LC to reconsider its policy. Following receipt of this letter, the Assistant Director of Cataloging responded that European and American exhibition catalogs indexed in the Worldwide Art Catalog Bulletin would once again be given a high priority at LC.

According to Dr. Freitag, incoming chairman, the program at Detroit in June 1970 would center around three main points: (1) continuation of the Reprint Committee; (2) standards for nondestructive photo duplication; and (3) acquisitions and blanket orders of art materials.

Cooperative System of Ohio Art Libraries Venturi, Storia Dell arte Index

College Art Association Affiliation

Mrs. Jacqueline Sisson, Art Library, Ohio
State University, Columbus, Ohio.

Report was given by Mrs. Sisson on the cooperative art libraries program initiated by her in Ohio. Program includes inventory of holdings to determine strengths and weaknesses of participating libraries, cooperative book selection, photoduplication, and interlibrary loan policies. Details will appear in CBL News.

Mrs. Sisson gave a progress report of her project indexing Venturi's Storia dell'arte italiana.

Mrs. Sisson was appointed chairman of a committee investigating affiliation with the College Art Association.

\section{Fine Arts Bibliography Course}

TaUght AT Kentucky

Professor John Larsen, School of Library

Science, University of Kentucky, Lexington.

Professor Larsen outlined the approach in his own Fine Arts Bibliography course taught at Kentucky and reported on those taught at Queens College, Columbia University, and the University of North Carolina.

\section{From Inside the DLP}

\section{By Dr. Katharine M. Stokes}

College and University Library Specialist, Library Planning and Development Branch, Division of Library Programs, Bureau of Adult, Vocational, and Library Programs, U.S. Office of Education, Washington, D.C. 20202.

As this article is being written, ten days before Christmas, application forms for College Library Resources grants (Title II-A, Higher Education Act) are being mailed to presidents of institutions of higher education, specifying February 20, 1970, as the deadline for return to our offices. The instructions accompanying them have a special note at the bottom of the first page. The note states that no special purpose grants will be made in fiscal year 1970 and basic grants will not exceed $\$ 2,500$; but "In the event that the level of funding for fiscal year 1970 is substantially altered from the level anticipated, then further instructions will be sent to all institutions of higher education advising them of any and all program changes for fiscal year 1970."

The anticipated level of funding for fiscal year 1970 is $\$ 12,500,000$, half the amount appropriated for each of the last three years. Duplicate application forms are being sent to college and university librarians with letters stating that no substantive changes were made from last year's requirements for basic and supplemental grants and urging that the applications be submitted as soon as possible. We hope that many will come in before the deadline date, because funds for extra help to process the 4,100 or more applications probably will be severely limited. Last year 2,282 applications for basic grants and 1,808 for supplemental grants were processed.

This year, for the first time, colleges planning to enroll students by the fall of 1971 may apply for basic grants. Formerly, only those institutions with students already attending classes were eligible for basic grants, so the number of applications may be somewhat higher than last year's. Any librarian who thinks his institution would be eligible under the amended legislation should read very carefully section $131.2(\mathrm{~m})$, pts. $1-6$, on page 4 of the Regulations accompanying the application form.

The eighty-five fiscal year 1970 applications for grants to support institutes for training in librarianship (Title II-B, Higher Education Act) were evaluated by a visiting panel of twenty library educators and librarians just before Thanksgiving. Because of the decrease in the scheduled appropriation, it is anticipated that forty short-term institutes will be funded 